\title{
A New Species of The Sand Bees, Andrena Fabricius, 1775 (Hymenoptera, Andrenidae) From Kurdistan Region-Iraq
}

\author{
Havall M. Amin ${ }^{1}$ and Nabeel A. Mawlood ${ }^{2}$
}

1 Department of Plant Protection, Bakrajo Technical Institute, Sulaimani Polytechnic University

2 Department of Plant Protection, College of Agriculture, University of Salahaddin

\section{Article Info}

Received: April, 2019

Revised:April,2019

Accepted:May,2019

\section{Keywords}

Andrena, Andrenidae, Hymenoptera, Iraq, New species.

\section{Corresponding Author}

Havall.amin@spu.edu.iq

\section{Abstract}

A New species of sand bees, Andrena bakrajoensis sp. nov. was described from Iraq. This species differs from closely related species A. vetula Lepeletier, 1841 by, the body and metanotum are brown-reddish colors; anterior and posterior margin of labrum strongly of convex; mandibles without dentition. The important taxonomic characters have been described and illustrated.

\section{Introduction}

Andrena Fabricius, 1775 (Hymenoptera: Andrenidae), typically referred to as sand or solitary mining bees; according to present day classification in numbers of species (Michener, 2007). The genus nearly worldwide in distribution, includes about 1500 valid species to date and about as many synonyms (Gusenleitner and Schwarz, 2002). The real number of species of Andrena might approach 2000 (Dubitzky, 2006). The genus Andrena is the most numerous bee genera within the Holarctic and can be considered as one of the great important pollinators of spring-blooming plants and bushes
(Delaplane and Mayer, 2000). The genus Andrena F. was first recorded by (Moraitz 1876) from central Asia mainly from Uzbekistanm, he recorded 68 species (51 species were new to science). The taxonomy of Andrena for the western Palearctic region has been studied by (Warncke (1980). Many studies have been conducted from Central Asia by (Osytshnjuk et al., 2005, 2008; Tadauchi, 2006, 2008; Shebl and Tadauchi, 2009). In Iraq, Derwesh (1965) recorded 24 species of the family, included four species from the genus: Andrena , A.cordialis Morawitz 1877; A. cyanescens; Nyl. (=Andrena 
viridescens Viereck, 1916; A. flavipes Panzer, 1799 and A. vetula Lepeletier, 1841). Shalli and Fat-hullah (1986) recorded a new species from the genus Andrena in Sulaimani. This work aims to describe of a new species Andrena bakrajoensis sp. nov. which was collected from the flower of a purple star thistle, Centaurea calcitrapa L. in Iraq.

\section{Material and Methods}

The specimens were collected by sweep net from the flowers of a purple star thistle, Centaurea calcitrapa in Bakrajo, Sulaimani governorate Kurdistan Region-Iraq in 22. May.2014.

The specimens placed in boiling water for 10-15 minutes to soften their parts. The mouthparts and abdomen was separated and cleared in a hot solution of $10 \% \mathrm{KOH}$; after clearing, they were studied under immersion in distilled water. Additionally, these were dehydrated in a progressive ethanol series $(50 \%, 70 \%, 90 \%$ and $100 \%$ ) respectively, for two minutes of each concentration, then placed in xylol for two minutes, for translucency and mounted in D.P.X solution on a microscopic slide (Lane and Grosskey, 1993; El-Aw et al., 2012; Mawlood et al., 2016). The habitat and important features photographs were taken using a digital camera (AmScope Microscope Camera); the measured proportions of body parts are given in points of an eye piece linear micrometer in a binocular microscope.

The genus were identified depending of available literature of (Michener, 2007; Scheuchl and Hazir, 2008; Ariana et al., 2009) and the help of Prof. Dr. Mohammed Salah Abdul-Rassoul, Iraq Natural History Research Center and Museum, University of Baghdad and Assist. Prof. Dr. Ali Raza Monfared in Yasuj University-Iran.

\section{Results and Discussions \\ Discription}

Andrena bakrajoensis sp. nov.
Body: Female (Pl.1 a, b), slender, reddishbrown, slightly convex, body length $12.5 \mathrm{~mm}$.

Head: Nearly triangular, reddish-brown, much broader than it long, length $3.3 \mathrm{~mm}$; width 4.2 $\mathrm{mm}$. Eyes oval, brown, bare, inner orbital margin are strongly concave, upper interorbital distance is $1.8 \mathrm{~mm}$ long, lower interorbital distance is $2.00 \mathrm{~mm}$. Vertex slightly concave, densely yellow setae. Frons is strongly convex, sparsely yellow setae. Facial fovea is present. Clypeus slightly convex, brown, coarsely punctuate, sparsely yellow setose, much broader than length, anterior margin strongly concave, with row of yellow setae apically; malar space narrow. Labrum (Fig. 1a) nearly rectangular, brown, length $0.55 \mathrm{~mm}$, impunctuate, surface bare, anterior and posterior margin strongly convex, clothed by yellow setae, apical margin with densely yellow setae. Mandible (Fig. 1b) dark brown, length $1.8 \mathrm{~mm}$, densely yellow setae laterally, base slightly broader than apex, without dentition. Maxilla (Fig. 1c) light-dark brown, stipes oval; inner margin densely long yellow hairs, without comb in strong concavity of posterior stipital margin; lacinia present scalelike lobe with hairs near base of galea; galea with postpalpal part usually much shorter than stipes and with densely yellow hairs. Maxillary palp consists of six segments without setae, 2nd segment tubular shaped,1.4 times as long as 1st segment; 3rd segment 1.2 times as long as 4th segment; 5th and 6th segments equal in size. Labium, 1st segment elongate and flattened, 1.1 times as long as 2nd segment and without setae, 2nd and 3rd segments cup shaped like, equal in size 1.2 times as long as 4th segment, without setae, 4th segment tubular. Glossa short, 4.2 times as shorter than prementum and covered with densely yellow setae; paraglossa short and membranous. Antennae (Fig. 1d) reddish-brown, 1st flagellomere 4.3 times as long as 2nd.

Thorax: Pronotum black with densely yellow setae, anterior and posterior margins concave. Mesonotum rounded and brown-reddish color, 
coarsely punctuate, densely yellow setose, anterior and posterior margin strongly convex. Parapsidal line linear. Axillae round. Metanotum brown-reddish color covered with sparsely yellow setae. Prosternum brown, impunctuate with densely yellow setae, anterior and posterior margin concave. Mesosternum brown, impunctuate,with densely yellow setae. Propodeum nearly rectangular, reddish-brown, coarsely punctuate with densely yellow setae, anterior and posterior margins concave. Forewing (Fig. 1e) hyaline ,length $8.1-8.6 \mathrm{~mm}$, apex of marginal cell strongly rounded, gradually bent away from wing margin; basal vein slightly curved, about 1.8 times as shorter than marginal cell, three submargianl cells, 2r-m strongly arched, 1st submarginal cell as long as 2nd and 3rd submarginal cells combined. Metatibia and Metabasitarsus(Fig. 1f) densely yellow setae, metatibia with apical margin without comb of setae (Rastellum). Hind tibial spurs present. Pretarsi with arolia. Each claw with minute inner tooth.

Abdomen: Elongated oval, reddish- brown consist of six visible segments, abdominal sternites with fin punctures and sparsely setose, tergites covered by densely yellow hair bands apically. 6th abdominal sternite (Fig. 1g) triangular, apical part sparsely yellow setose. 7th abdominal sternite (Fig. 1h) cup shaped, apical part with densely yellow setae.

Type Material: ( $\hat{\delta}$ ) (Holotype) Iraq-Kurdistan region-Sulaimani, Bakrajo district, $350 \mathrm{~km} \mathrm{~N}$ Baghdad, 22. May. 2014 from purple star thistle, Centaurea calcitrapa; Paratype (4 송 6 우 우): from same locality; The Holotype is kept in the Insect Museum-Department of Plant Protection, College of Agriculture, Salahaddin University.

Diagnosis: Andrena bakrajoensis sp. nov.: This species differs from closely related species A. vetula Lepeletier, 1841 by the following characters: Body reddish-brown, length 12.5 $\mathrm{mm}$. Labrum nearly rectangular, impunctuate, surface bare, anterior and posterior margins strongly convex. Mandibles without dentition. Metanotum reddish- brown color.

Male: Unknown

\section{Acknowledgments}

We sincerely thank the specialist Assist. Prof. Dr. Ali Raza Monfared in Yasuj University-Iran for his kind help in identifying the genus of this species. We deeply express our gratitude to Prof. Dr. Mohammed Salah Abdul Rassoul in Division of Entomology, Natural History Research Center - University of Baghdad, Iraq for his kind help and assistance in confirming of the genus.

\section{References}

[1] Ariana, A., Scheuchl, E., Tadauchi, O. and Gusenleitner, F. 2009. A taxonomic revision of the subgenus Andrena (Brachyandrena) (Hymenoptera: Andrenidae). Zootaxa, 2281: 2139.

[2] Delaplane, K. and Mayer, D. 2000. Crop Pollination by Bees. CABI Publishing, New York, 344 pp.

[3] Derwesh, A.I. 1965. A preliminary list of identified insects and arachnids of Iraq. Directorate General Agriculture Resources Project Baghdad, Bulletin, 121-123.

[4] El-Aw, M.A., Draz, K.A., Eid, K.S.A. and Abo-Shara, H. 2012. Measuring the morphological characters of honeybee (Apis mellifera L.) using a simple semi- automatic tech nique. Journal of American Science, 8 (3): 558564.

[5] Gusenleitner, F. and Schwarz, M. 2002. Checklist of the bee genus Andrena with remarks and further information on the Palearctic species (Hymenoptera: Andrenidae). Entomology suppllier, 12: 1280.

[6] Lane, R.P. and Crosskey, R.W. 1993. Medical insects and arachnids. The Natural History Museum, Chapman and Hall, London, 723 PP.

[7] Mawlood, N.A., Hamad, M.I. and Abdullah,Y.M. 2016. A new record of glaphyrid scarab beetles, Eulasia vitatta (Fabricius, 1775) 
(Coleoptera, Glaphyridae) from Erbil Kurdistan Region-Iraq. Zanco Journal of Pure and Applied Sciences, 28 (3): 1-4.

[8] Michener, C.D. 2007. The bees of the world.

Baltimore \& London: Johns Hopkins, University Press, 953 PP.

[9] Morawitz, F. 1876. Bienen (Mellifera) II. Andrenidae. In: Fedtschenko A. P., Reisen in Turkestan II. Izv. imp. Obshch. Ljubit. Estest. Antrop. Etnog., 21: 161-303.

[10] Osytshnjuk, A.Z., Romasenko, L., Banaszak, J. and Cierzniak,T. 2005. Andrenidae of the Central and Eastern Palaearctic. Part 1. prodruk, Poznan, 235 pp.

[11] Osytshnjuk, A.Z., Romasenko, L., Banaszak, J. and Cierzniak,T. 2008. Andrenidae of the Central and Eastern Palaearctic. Part 2. prodruk, Poznan, 233 pp.

[12] Scheuchl, E. and Hazir, C. 2008. Correspondence Description of a new Andrena species from Turkey, Andrena (Notandrena) selcuki n. sp. (Hymenoptera: Apoidea, Andrenidae). Zootaxa, 1763: 63-66.
[13] Shalli, R.A. and Fat-hullah, B.S. 1986. List of identified insects and Arachnids of Sulaimani region. State Board for Applied Agricultural Research-Plant Protection Research-Bakrajo, 63pp.

[14] Shebl, M. and Tadauchi, O. 2009. The genus Andrena from Kazakhstan and Kyrgyzstan (Hymenoptera, Andrenidae) (3). Esakia, 49: 2162.

[15] Tadauchi, O. 2006. The genus Andrena from Kazakhstan and Kyrgyzstan collected by the Kyushu University Expedition (Hymenoptera, Andrenidae) (1). Esakia, 46: 119.

[16] Tadauchi, O. 2008. The genus Andrena from Kazakhstan and Kyrgyzstan collected by the Kyushu University Expedition (Hymenoptera, Andrenidae) (2). Esakia, 48: 118.

[17] Warncke, K. 1980. Zur Verbreitung der Bienengattung Andrena F. in Tunesien (Hymenoptera, Apidae). Mitteilungen der Münchner Entomologischen Gesellschaft, 70: 65-87. 


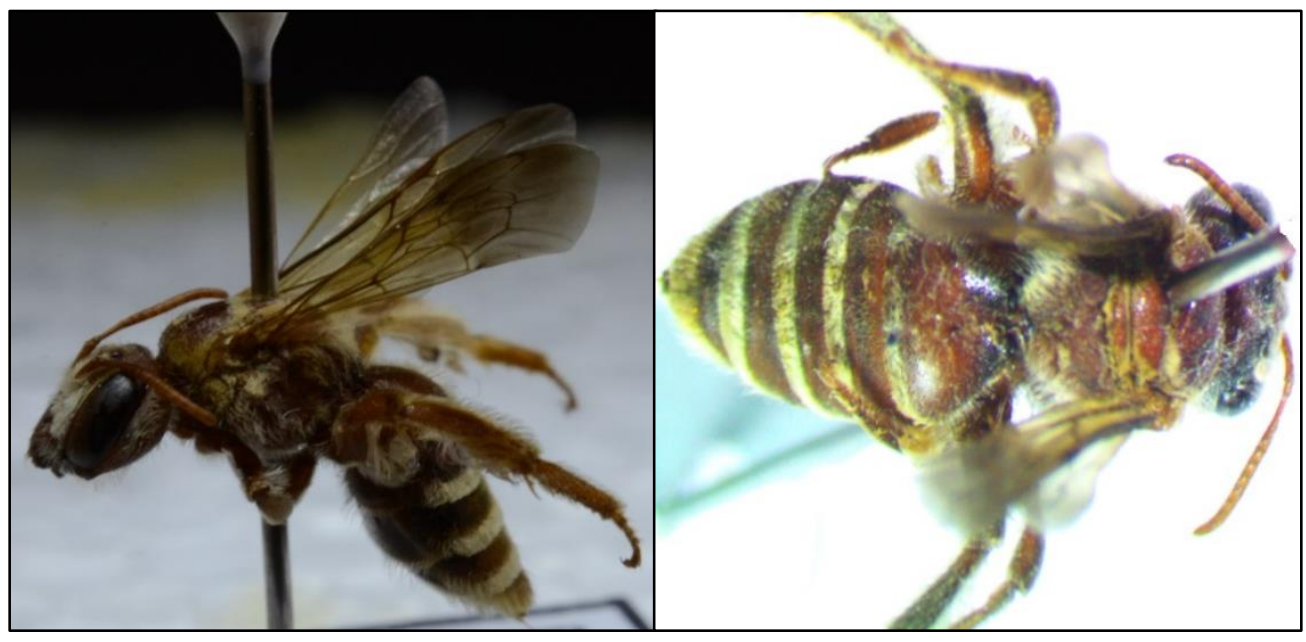

(a)

(b)

Plate (1): Andrena bakrajoensis sp. nov.
a. Female (Lateral view)
b. Female (Dorsal view)

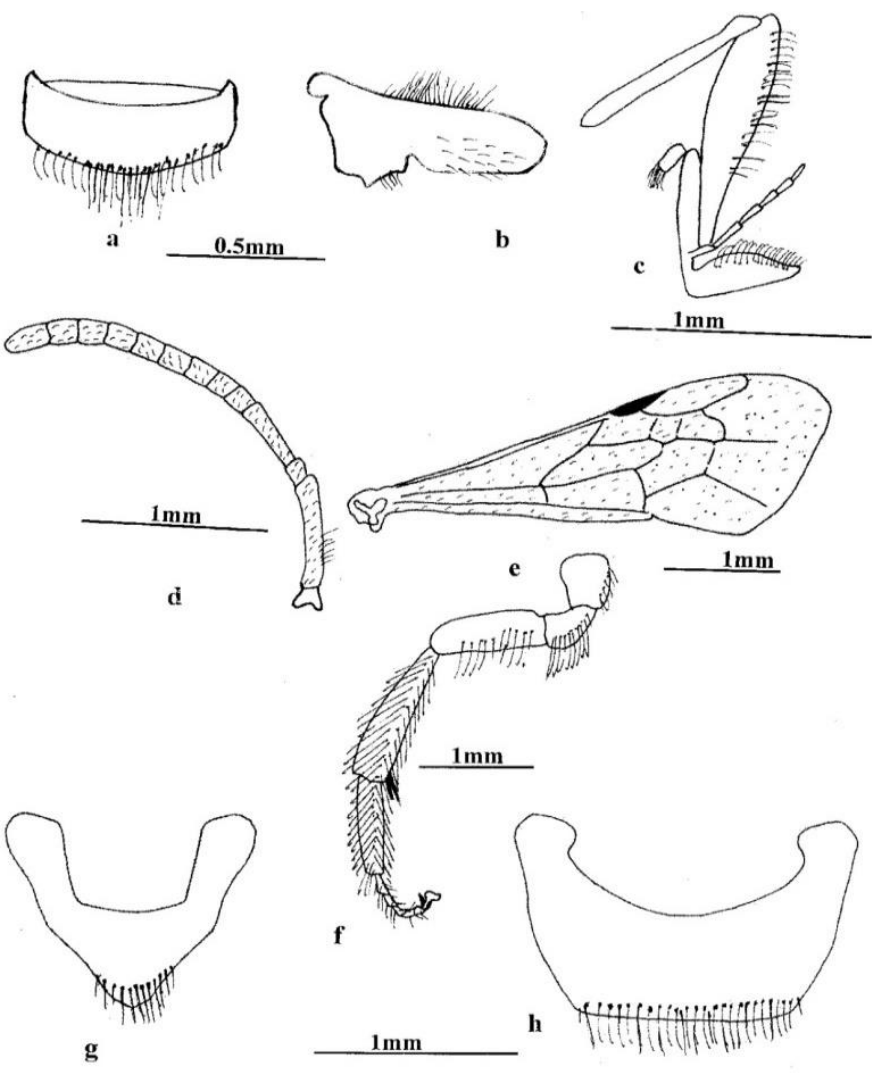

Figure (1): Andrena bakrajoensis sp. nov.
a. Labrum
b. Mandible
c. Maxilla
d. Antennae
e. Forewing
f. Foreleg
g. 6 th abdominal sternite h. 7th abdominal sternite 